\title{
PENGARUH METODE LATIHAN DRILL TERHADAP KETERAMPILAN SERVIS BAWAH PERMAINAN BOLA VOLI
}

\section{THE EFFECT OF DRILL TRAINING METHODS ON UNDERWIDE SERVICE SKILLS}

\author{
Ruslan \\ Program Studi Pendidikan Jasmani Kesehatan dan Rekreasi \\ Fakultas Olahraga dan Kesehatan, Universitas Negeri Gorontalo \\ Kontak Penulis: ruslan@ung.ac.id
}

\begin{abstract}
ABSTRAK
Tujuan dari penelitian ini adalah untuk mengetahui adanya pengaruh metode latihan drill terhadap keterampilan servis bawah permainan bolavoli pada siswa SMP Negeri 3 Satap Dungaliyo. Jenis penelitian ini adalah eksperimen dengan desain penelitian berbentuk one group, pre test dan post test, populasi dalam penelitian ini adalah siswa SMP Negeri 3 Satap Dungaliyo yang berjumlah 121 orang yang terdiri dari 5 kelas, jumlah sampel yang di ambil dari kelas VIII 1 yaitu sabanyak 24 orang, cara pengambilan sampel dalam penelitian ini dengan cara purposive sampling. Instrumen penelitian menggunakan panduan penilaian kelompok mata pelajaran jasmani olahraga dan kesehatan. Setelah dilakukan analisis diperoleh nilai rata-rata tes awal adalah 62,49 dan tes akhir meningkat sebesar 80,55. Hal ini menunjukkan bahwa responden yang menjadi sampel dalam penelitian ini memperoleh peningkatan hasil rata-rata dari tes awal sampai tes akhir dengan selisih peningkatan dari hasil Pre-test dan post-test sebesar 18,06. Simpulannya bahwa metode latihan drill dapat meningkatkan Keterampilan Servis Bawah Permainan Bola Voli pada siswa Kelas VIII Di SMP 3 Satap Dungaliyo.
\end{abstract}

Kata kunci: latihan drill; servis bawah; Bola voli

\begin{abstract}
The purpose of this study was to determine the effect of the drill training method on the bottom serve skills of the volleyball game in the students of SMP Negeri 3 Satap Dungaliyo. This type of research is an experimental research design in the form of one group, pre test and post test, the population in this study are students of SMP Negeri 3 Satap Dungaliyo totaling 121 people consisting of 5 classes, the number of samples taken from class VIII 1 is as many as 24 people, the sampling method in this study was purposive sampling. The research instrument uses a group assessment guide for physical sports and health subjects. After the analysis, the average score for the initial test was 62.49 and the final test increased by 80.55. This shows that the respondents who became the sample in this study obtained an increase in the average result from the initial test to the final test with a difference of 18.06 increase from the results of the pre-test and post-test. The conclusion is that the drill training method can improve the Volleyball Game Lower Service Skills in Class VIII students at SMP 3 Satap Dungaliyo.
\end{abstract}

Keywords: drills; underwide service; Volleyball 


\section{PENDAHULUAN}

Kegiatan belajar yang berlangsung di sekolah yang bersifat formal, disengaja direncanakan dengan bimbingan guru dan bentuk pendidik lainnya (Dai et al., 2021). Apa yang hendak dicapai dan dikuasai oleh siswa dalam tujuan belajar, dipersiapkan bahan yang harus dipelajari, dipersiapkan juga metode pembelajaran yang sesuai dan dilakukan evaluasi untuk mengetahui kemajuan belajar siswa.

Sejalan dengan permasalahan belajar mengajar, kegiatan pembelajaran pendidikan jasmani di sekolah selalu terkait langsung dengan tujuan yang jelas (Hadjarati \& Haryanto, 2020). Dalam hal ini secara umum tujuan pendidikan jasmani dapat diklasifikasikan menjadi empat kelompok yaitu: (1) Perkembangan fisik, (2) perkembangan gerak, (3) perkembangan moral dan (4) perkembangan sosial. Melalui pendidikan jasmani diharapkan bisa merangsang perkembangan sikap, mental, sosial, emosi yang seimbang serta keterampilan gerak siswa. Begitu pentingnya peranan pendidikan jasmani di sekolah maka harus diajarkan secara baik dan benar.

Bola voli merupakan salah satu cabang olahraga permainan yang termasuk dalam materi pokok pendidikan jasmani (Rizal \& Kasriman, 2020). Banyak manfaat yang diperoleh dengan bermain bola voli yang diantaranya adalah dapat membentuk sikap tubuh yang baik meliputi anatomis, fisologis, kesehatan dan kemampuan jasmani. Manfaatnya bagi rohani yaitu kejiwaan, kepribadian dan karakter akan tumbuh kearah yang sesuai dengan tuntutan masyarakat.

Permainan bola voli merupakan suatu permainan yang kompleks yang tidak mudah di lakukan oleh setiap orang (Duhe \& Haryanto, 2021). Sebab, dalam permainan bola voli dibutuhkan koordinasi gerak yang benar - benar bisa diandalkan untuk melakukan semua gerakan yang ada dalam permainan bola voli. Dalam permainan bola voli ada beberapa bentuk teknik yang harus dikuasai, teknik - teknik dalam permainan bola voli terdiri atas servis, passing, block dan smash.

Servis merupakan awal dimulainya suatu permainan bola voli. Dalam melakukan servis ada beberapa macam cara atau model, yaitu : Servis bawah (underhand server), Servis atas (overhead serve), dan Servis lompat (jump serve) (Sari \& Guntur, 2017). Servis bawah adalah servis yang sangat sederhana dan diajarkan terutama untuk pemain pemula. Gerakannya lebih alamiah dan tenaga yang dibutuhkan tidak terlalu besar (Widhiasto et al., 2020).

Penggunaaan metode pembelajaran yang tepat bagi siswa yang sedang belajar servis akan memudahkan pelaksanaan proses belajar mengajar guna mencapai tujuan yang ditetapkan (Sari \& Guntur, 2017). Adapun salah satu metode pembelajaran yang dapat digunakan untuk meningkatkan kemampuan servis bola voli yaitu metode drill (Zetou et al., 2012). Dari metode pembelajaran tersebut memiliki karakteristik yang belum diketahui yang lebih baik dan efektif untuk meninggkatkan proses pembelajaran dan keterampilan servis bahwa dalam permainan bola voli pada siswa kelas VIII SMP Negeri 3 Satap Dungaliyo yang sedang dalam taraf belajar.

Penggunaan pendekatan pembelajaran yang tepat bagi siswa yang sedang belajar servise akan memudahkan pelaksanaan proses belajar mengajar guna mencapai tujuan yang telah ditetapkan (Ridwan, 2016). Adapun salah satu pendekatan peembelajaran yang dapat digunakan 
untuk meningkatkan kemampuan servis bola voli yaitu metode latihan drill.

\section{METODE PENELITIAN}

Desain penelitian yang digunakan adalah One-Group Pretesst-Posttest Design. Populasi dalam penelitian ini adalah siswa SMP Negeri 3 Satap Dungaliyo yang terdaftar pada tahun pelajaran 2017/2018 dengan jumlah siswa keseluruhan 121 orang yang terdiri dari 5 Kelas. Sampel dalam penelitian ini adalah siswa kelas VIII 1 SMP Negeri 3 Satap Dungaliyo yang berjumlah 24 orang siswa diantaranya siswa laki-laki 12 orang dan siswa perempuan 12 orang. Oleh karena itu, penelitian menggunakan teknik sampel Purposive Sampling. Instrumen penelitian menggunakan panduan penilaian kelompok mata pelajaran jasmani olahraga dan kesehatan (Kebudayaan, 2014).

Data yang dikumpulkan dalam penelitian ini adalah data dari hasil tes dan Pretest dilakukan untuk mengambil data sebelum diberikan perlakuan (treatment), yang digunakan untuk mengukur hasil belajar siswa. Pemberian perlakuan dengan menggunakan metode latihan drill, proses pencapaian kemampuan dapat dicapai dan dapat dilihat. Pengambilan data post test juga diambil dari hasil tes kemampuan servis bawah pada bolavoli yang dilakukan setelah akhir perlakuan (treatment).

Sebelum data di uji, maka di lakukan pengujian persyaratan analisis yaitu uji normalitas data dengan uji liliefors. Untuk menguji hipotesis penelitian yang menyatakan bahwa ada pengaruh metode latihan drill terhadap keterampilan servis bawah, digunakan teknik uji t.

\section{HASIL PENELITIAN}

Dari hasil pengukuran diperoleh data keterampilan servis bawah permainan bola voli pada siswa kelas VIII SMP 3 Satap Dungaliyo baik pre-test dan post-test, hasilnya dapat dilihat pada diagram berikut:

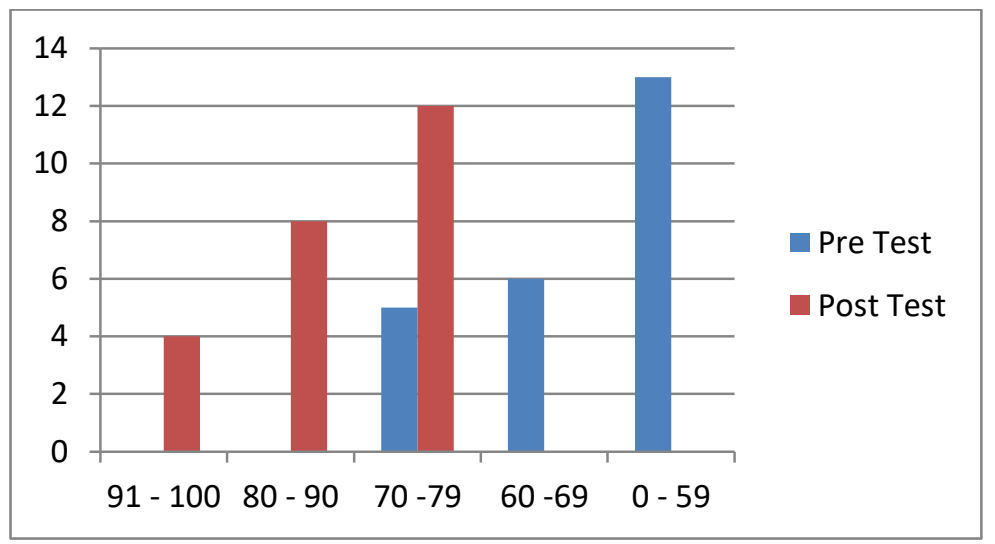

Gambar 1. Hasil pre-test dan post-test

Dalam penelitian ini, yang menjadi variabel $\mathrm{X}_{1}$ adalah skor data yang diperoleh melalui pengukuran pre-test atau tes awal keterampilan servis bawah sebelum eksperimen dilakukan atau sebelum diberikan metode latihan drill. Dari hasil tes diperoleh skor tertinggi yaitu 75 dan skor terendah adalah 50 Setelah dilakukan analisis diperoleh skor rata-rata sebesar 62,49. 
Dilihat dari pengukuran besaran-besaran statistik di atas dapat diartikan bahwa keterampilan servis bawah siswa kelas VIII SMP 3 Satap Dungaliyo, sebelum diberikan metode latihan drill, menunjukkan skor yang tidak terlalu jauh berbeda dengan skor rata-rata, akan tetapi keterampilan servis bawah tersebut masih dibawah rata-rata.

\section{PEMBAHASAN}

Pembelajaran dapat didefinisikan sebagai suatu sistem atau proses membelajarkan subjek didik/pembelajar yang direncanakan atau didesain, dilaksanakan, dan dievaluasi secara sistematis agar subjek didik/pembelajar dapat mencapai tujuan-tujuan pembelajaran secara efektif dan efisien (Sudibyo \& Nugroho, 2020). Permainan bola voli adalah permainan yang berbentuk memukul bola diudara hilir mudik di atas net, dengan maksud dapat menjatuhkan bola di daerah petak lawan untuk mencari kemenangan dalam permainan. memvoli dan memantulkan bola ke udara harus mempergunakan bagian tubuh mana saja, asalkan dengan pantulan yang sempurna (Rizal \& Kasriman, 2020). Dalam permainan bola voli untuk mengawali permainan diperlukan servis. Servis merupakan berbagai jenis teknik dasar bola voli. Dalam latihan maupun permainan, perlu sangat di tonjolkan pentingnya servis yang tepat dan aman karena penentuan awal permainan berada pada tingkat ketajaman dan ketepatan servis.

Dalam proses pembelajaran banyak faktor didalamnya yang saling mempengaruhi misalnya metode latihan Drill hal ini terjadi memang berperan penting dalam penyusunan strategi pelaksanaan kegiatan. Oleh karena itu metode latihan Drill yang dipergunakan dalam meningkatkan keterampilan servis bawah masih perlu diuji efektifitas dan efisien (Wahyu Cirana et al., 2021). Hal ini menyebabkan perlu adanya pengujian terhadap efektifitas dan efisiensi metode latihan yaitu karena adanya perbedaan karakteritik dan prinsip yang dianut oleh masingmasing cabang olahraga. Dengan demikian dapat dikatakan bahwa tak satu pun metode latihan yang lebih baik. Metode latihan harus didasarkan pada apa yang diajarkan, oleh siapa, kepada siapa, pada kondisi bagaimana dan untuk tujuan apa.

Hasil analisis deskripitif dan pengujian hipotesis memperhatikan gambaran bahwa ada pengaruh metode latihan drill terhadap Keterampilan Servis Bawah Permainan Bola Voli pada siswa Kelas VIII Di SMP Negeri 3 Satap Dungaliyo. Hal ini memberikan indikasi bahwa kemampuan servis bawah bola pada permainan bola voli yang diajar dengan metode latihan drill mempunyai hasil belajar yang cenderung lebih baik dibandingkan dengan keterampilan servis bawah siswa yang tidak diajar dengan metode latihan $d$ rill.

Berdasarkan hasil penelitian pre-test menunjukkan skor tertinggi 75 dan skor yang terendah 50. Setelah dilakukan analisis diperoleh nilai rata-rata 62,49 dan nilai standar deviasi 7,7 dan varians 58,71. Sedangkan pada hasil penelitian post-test menunjukkan skor tertinggi 91,66 dan skor terendah 75. Setelah dilakukan analisis diperoleh nilai rata-rata 80,55 dan standar deviasi 6,4 serta varians 41,42. Hal ini menunjukkan bahwa responden yang menjadi sampel dalam penelitian ini memperoleh peningkatan hasil rata-rata dari tes awal sampai tes akhir dengan selisih peningkatan dari hasil Pre-test dan post-test sebesar 18,06.Untuk keperluan pengujian hipotesis dalam penelitian ini, maka dalam pengujian hipotesis digunakan uji analisis 
data penelitian eksperimen. Untuk menganalisis data eksperimen yang menggunakan pre-test dan post-test design.

Dari hasil pengujian hasil pre-test dan post-test menunjukkan harga $\mathrm{t}_{\text {hitung }}$ sebesar 22,1. Sedangkan dari daftar distribusi diperoleh harga $\mathrm{t}_{\text {daftar }}$ atau $\mathrm{t}_{(0,995(23)}=2.81$. Ternyata harga $\mathrm{t}_{\text {hitung }}$ telah berada di dalam daerah penerimaan $\mathrm{H}_{\mathrm{A}}$. Dengan demikian dapat disimpulkan bahwa $\mathrm{H}_{\mathrm{A}}$ diterima dan tidak dapat menerima $\mathrm{H}_{\mathrm{o}}$. Jadi dapat disimpulkan bahwa metode latihan drill dapat meningkatkan Keterampilan Servis Bawah Permainan Bola Voli pada siswa Kelas VIII Di SMP Negeri 3 Satap Dungaliyo.

\section{KESIMPULAN}

Setelah dilakukan analisis diperoleh nilai rata-rata tes awal adalah 62,49 dan tes akhir meningkat sebesar 80,55. Hal ini menunjukkan bahwa responden yang menjadi sampel dalam penelitian ini memperoleh peningkatan hasil rata-rata dari tes awal sampai tes akhir dengan selisih peningkatan dari hasil Pre-test dan post-test sebesar 18,06.Untuk keperluan pengujian hipotesis dalam penelitian ini, maka dalam pengujian hipotesis digunakan uji analisis data penelitian eksperimen. Dari hasil pengujian hasil pre-test dan post-test menunjukkan harga $t_{\text {hitung }}$ sebesar 22,1. Sedangkan dari daftar distribusi diperoleh harga $t_{\text {daftar }}$ atau $t_{(0,995(23)}=2.81$. Ternyata harga $t_{\text {hitung }}$ telah berada di dalam daerah penerimaan $\mathrm{H}_{\mathrm{A}}$. Dengan demikian dapat disimpulkan bahwa $\mathrm{H}_{\mathrm{A}}$ diterima dan tidak dapat menerima $\mathrm{H}_{\mathrm{o}}$. Jadi dapat disimpulkan bahwa metode latihan drill dapat meningkatkan Keterampilan Servis Bawah Permainan Bola Voli pada siswa Kelas VIII Di SMP Negeri 3 Satap Dungaliyo.

\section{REFERENSI}

Dai, A., Hadjarati, H., \& Haryanto, A. I. (2021). Gaya resiprokal untuk meningkatkan keterampilan shooting bola basket. Altius: Jurnal Ilmu Olahraga Dan Kesehatan, 10(1), 53-65. https://doi.org/http://dx.doi.org/10.36706/altius.v10i1.14056

Duhe, E. D. P., \& Haryanto, A. I. (2021). Persepsi Kinestetik, Koordinasi Mata Tangan dan Motivasi terhadap Jump Smash. Sporta Saintika, 6(1), 1-18. https://doi.org/https://doi.org/10.24036/sporta.v6i1.156

Hadjarati, H., \& Haryanto, A. I. (2020). Motivasi Untuk Hasil Pembelajaran Senam Lantai. Multilateral Jurnal Pendidikan Jasmani Dan Olahraga. https://doi.org/10.20527/multilateral.v19i2.8646

Kebudayaan, K. P. dan. (2014). Pendidikan Jasmani, Olahraga, dan Kesehatan SMP/MTS Kelas VII (Revisi). Kementerian Pendidikan dan Kebudayaan.

Ridwan, M. (2016). Pengaruh Keseimbangan, Kelincahan Dan Motivasi Berolahraga Terhadap Keterampilan Passing Atas Bola Voli Di Sma Negeri 1 Panggarangan Kabupaten Lebak. Multilateral Jurnal Pendidikan Jasmani Dan Olahraga. https://doi.org/10.20527/multilateral.v15i1.2486

Rizal, B. T., \& Kasriman, K. (2020). Pengaruh Gaya Mengajar dan Koordinasi Mata Tangan Terhadap Keterampilan Smash Bola Voli. Jurnal MAENPO: Jurnal Pendidikan Jasmani Kesehatan Dan Rekreasi. https://doi.org/10.35194/jm.v10i2.1065

Sari, Y. B. C., \& Guntur, G. (2017). Pengaruh metode latihan dan koordinasi mata-tangan terhadap hasil keterampilan servis atas bola voli. Jurnal Keolahragaan. 
https://doi.org/10.21831/jk.v5i1.12773

Sudibyo, N. A., \& Nugroho, R. A. (2020). Survei Sarana Dan Prasarana Pembelajaran Pendidikan Jasmani Olahraga Dan Kesehatan Pada Sekolah Menengah Pertama Di Kabupaten Pringsewu Tahun 2019. Journal Of Physical Education, 1(1). https://doi.org/10.33365/joupe.v1i1.182

Wahyu Cirana, Arif Rohman Hakim, \& Untung Nugroho. (2021). Pengaruh Latihan Drill Smash Dan Umpan Smash Terhadap Keterampilan Smash Bola Voli Pada Atlet Putra Usia 13-15 Tahun Club Bola Voli Vita Solo Tahun 2020. JURNAL ILMIAH PENJAS (Penelitian, Pendidikan Dan Pengajaran), 7(1). https://doi.org/10.36728/jip.v7i1.1381

Widhiasto, R. W. W., Alsaudi, A. T. B. D., \& Suyatno, S. (2020). Meningkatkan Hasil Belajar Servis Bawah Bola Voli Mini melalui Pembelajaran Secara Bertahap. Jurnal Ilmu Pendidikan (JIP) STKIP Kusuma Negara, 11(2). https://doi.org/10.37640/jip.v11i2.158

Zetou, E., Vernadakis, N., Bebetsos, E., \& Makraki, E. (2012). The effect of self-talk in learning the volleyball service skill and self-efficacy improvement. Journal of Human Sport and Exercise. https://doi.org/10.4100/jhse.2012.74.07 